\title{
Maan vesipitoisuuteen vaikuttavien ominaisuuksien ja sateen vaikutus maksimaaliseen biomassan kertymiseen sekä paikkakohtaiseen vaihteluun
}

\author{
Mikko Hakojärvi $^{1)}$, Mikko Hautala $^{1)}$, Antti Ristolainen ${ }^{2)}$, Laura Alakukku ${ }^{1)}$ \\ ${ }^{1)}$ Maataloustieteiden laitos, PL28, 00014 Helsingin Yliopisto, mikko.hakojarvi@ helsinki.fi, \\ mikko.hautala@helsinki.fi, laura.alakukku@helsinki.fi \\ ${ }^{2)}$ MTT, Planta, 31600 Jokioinen
}

\section{TIIVISTELMÄ}

Viljelykasvin sato vaihtelee usein lohkon sisällä. Täsmäviljelyllä on pyritty vastaamaan tähän vaihteluun, mutta siinä onnistumiseen tarvitaan tietoa satovaihtelun syistä. Maan ominaisuuksien, erityisesti maan vesitalouteen liittyvien, on useissa eri tutkimuksissa todettu vaikuttavan sadon vaihteluun. Sadanta, maan hyötykapasiteetti, hydraulinen vedenjohtavuus ja kapillaarisuus vaikuttavat yhdessä viljelykasvin satoon, Niiden vaikutus satoon riippuu sadannan määrästä, maan ominaisuuksista ja viljelykasvin veden tarpeesta. Tästä syystä maan ominaisuuksien vaikutus sadon vaihteluun ei välttämättä ilmene jokaisella kasvukaudella.

Tässä tutkimuksessa sadon vaihtelua tarkasteltiin simuloimalla veden rajoittamaa potentiaalisen kevätvehnän (Triticum aestivum) biomassan kertymää paikkakohtaisesti kolmella eri lohkolla. Simuloinnissa käytettiin lohkoilta paikkakohtaisesti mitattuja maan ominaisuuksia ja maksimaalista biomassan kertymistä kuvaavaa kasvimallia. Biomassan kertymistä simuloitiin paikkakohtaisesti jokaisella lohkolla 1000 kasvukauden ajan. 1000 simuloidun kasvukauden välillä ainoa muuttuvana tekijänä oli sade, joka kausikohtaisesti luotiin omalla mallillaan. Sadon vaihtelun voimakkuutta arvioitiin menetelmällä, jossa biomassasadosta laskettiin lohkokohtainen keskisato ja ajallinen keskihajonta simuloiduille pisteille.

Simuloitu biomassasato oli kaikilla lohkoilla huomattavasti keskimääräistä alhaisempi vähäsateisina vuosina, jolloin sato vaihteli hieman enemmän kuin sateisina vuosina. Käytetyllä menetelmän ja simulointituloksien avulla pystyttiin löytämään ne alueet lohkoilla, joilla sato suurella todennäköisyydellä poikkeaa lohkon keskisadosta. Menetelmää käytettäessä on kuitenkin otettava huomioon, että se ei erottele sellaisia pisteitä, joissa sato pysyy toistuvasti samalla tasolla, mutta poikkeaa lohkon keskisadosta. Täsmäviljelyä ajatellen tieto vakaasti satoa tuottavista paikoista olisi hyödyllinen riippumatta sadon tasosta.

Asiasanat: Biomassa, vaihtelu, maalaji, sadanta, mallinnus.

\section{Johdanto}

Elektroniikan määrä maatalouskoneissa on kasvanut huomattavasti viimeisen parin vuosikymmenen kuluessa. Sen myötä nykyaikaisella maatalouskoneella on yhä useammin mahdollista kerätä paikkakohtaista tietoa lohkoilta eri työvaiheiden yhteydessä. Esimerkiksi puinnin yhteydessä voidaan mitata sadon määrä ja myös joitain laadullisia tekijöitä, kuten valkuaispitoisuutta (Risius ja Korte, 2010). Uutta ja jo olemassa olevaa tekniikka hyödyntämällä on mahdollista saada yhä enemmän tietoa sadon ja kasvuolosuhteiden vaihtelusta yksittäisen peltolohkon sisällä.

Maan ominaisuuksien paikkakohtainen vaihtelu luo eroja kasvuoloihin lohkon sisällä ja vaikuttaa sitä kautta kasvin kasvuun ja edelleen satoon (esim. Cox ym. 2003, Keller ym. 2012, Wood ym. 2003). Maan ominaisuuksista aiheutuva vaihtelu viljelykasvin kasvussa ei välttämättä ole samanlainen jokaisena kasvukautena, huolimatta siitä, että ero maan ominaisuuksissa olisi pysyvää. Kasvukaudella kasvuolosuhteet vaikuttavat eri tavoin viljelykasvin kasvuun, esimerkiksi kasvien veden käyttöön vaikuttavia tekijöitä ovat sateen määrän ja ajoittumisen lisäksi maan vedenjohtavuus, pidätyskyky ja lohkon ojituksen toimivuus. Osittain tästä syystä johtuen sadonvaihtelun on usein havaittu muuttuvan vuodesta toiseen (Hakojärvi ym. 2013a, Blackmore ym. 2003, Godwin ym. 2003). Tällöin lohkon satoisimmat alueet eivät välttämättä joka vuosi sijaitse samassa paikassa, vaan saattavat vaihtaa paikkaa kasvukaudesta riippuen. Tämä lisää viljelyn haastavuutta, mikäli esimerkiksi 
viljelypanoksia (kuten lannoitteet) haluttaisiin kohdentaa lohkon sisällä paikkakohtaisen sadontuottokyvyn mukaan, kuten täsmäviljelyssä on perinteisesti tehty.

Elektronisten lisävarusteiden tarjonnan kasvamisen myötä sadonmittauslaitteet ovat yhä yleisempi varuste puimureissa. Lohkon satokartta tarjoaa helpon ja houkuttelevan vaihtoehdon hankkia tietoa lohkon sisäisestä satovaihtelusta sekä käyttää tulevalla kasvukaudella tätä tietoa lannoitteen kohdistamiseksi lohkon satoisemmille alueille. Tästä syystä satokarttojen hyödyntämistä on tutkittu useissa eri tutkimuksissa, joissa niiden avulla on pyritty kohdentamaan lannoitteiden ravinteita lohkon korkeasatoisiin osiin (Basso et al. 2011, Blackmore et al. 2003, Godwin et al. 2003, Shanahan et al. 2008, Welsh et al. 2003a, b). Näissä tutkimuksissa lopputulos ei useimmiten ole ollut toivotun kaltainen, johtuen edellä mainitusta vaihtelusta lohkon korkeasatoisten alueiden sijainnin vaihtelusta. Siksi satokarttojen on todettu tuottavan arvokasta tietoa satovaihtelusta, mutta koska vaihtelu voi olla riippuvaista kasvukauden sääoloista, satokarttoja ei voi suoraan käyttää tulevan kasvukauden paikkakohtaisen sadon ennustamiseen tai lannoituksen lohkon sisäiseen kohdentamiseen (Blackmore ym. 2003, Godwin ym. 2003). Paikkakohtaisten maan ominaisuuksien (Wood ym. 2003), erityisesti maan veden läpäisevyyteen ja varastointikykyyn liittyvien ominaisuuksien on oletettu vaikuttavan suuresti viljelykasvin kasvuun (Blackmore ym. 2003, Godwin ym. 2003), etenkin hyvin sateisina tai vähäsateisina kasvukausina (Cox ym. 2003).

Tässä tutkimuksessa simuloitiin kevätvehnän maksimaalista biomassan kertymistä paikkakohtaisesti kolmella eri peltolohkolla. Koska maan vedenpidätyskyvyllä ja vedenjohtavuudella on oletettu olevan suuri vaikutus sadon vaihteluun ja satotasoon, maan kosteutta simuloitiin omalla mallillaan, jossa käytettiin parametreina pelloilta paikkakohtaisesti mitattuja arvoja. Nämä paikkakohtaisesti mitatut maan ominaisuudet olivat saturoitunut hydraulinen vedenjohtavuus $\left(\mathrm{K}_{\mathrm{sat}}\right) \mathrm{ja}$ tilavuuskosteudet saturoituneena $(\mathrm{SWC}, 0 \mathrm{kPa})$, kenttäkapasiteetissa $(\mathrm{FC},-10 \mathrm{kPa})$ ja lakastumisrajalla (PWP, -1500 kPa). Simuloitu maan kosteus vaikutti edelleen simuloituun biomassan kertymiseen, jota maan veden riittävyyden lisäksi rajoitti ainoastaan auringon säteilyn määrä. Näin pystyttiin selvittämään pelkästään veden saatavuuden vaikutus biomassan kertymiselle, joka on hyvin riippuvainen kasvukauden sadannasta sellaisilla tuotantokasveilla, joita ei kastella. Jotta maaperän ominaisuuksien vaihtelu saataisiin luotettavasti selville, simulointiin biomassan kertymistä 1000 kasvukauden ajan sademääriä varioiden. Koska säädataa ei ollut näin pitkältä ajalta käytettävissä, simuloitujen kasvukausien sateet simuloitiin omalla mallillaan. Sadantojen laatimiseen käytettiin Kilpeläisen ym. (2008) kehittämää mallia, jolla pystytään luomaan tilastollisesti todenmukaista sadetta Etelä-Suomen olosuhteisiin.

\section{Aineisto ja menetelmät Potentiaalisen biomassan kertymisen kasvimalli}

Maksimaalisen biomassan kertymisen kuvaamiseen tässä tutkimuksessa käytettiin mallia, joka kuvaa C3-kasvien potentiaalisen biomassan kertymistä (Hautala ja Hakojärvi, 2011). Tässä mallissa biomassan kertymistä voivat rajoittaa vain auringosta tulevan säteilyn määrä tai veden saatavuus. Muiden tekijöiden kuten rikkakasvien, kasvitautien, tuholaisten tai maan märkyyden ei oleteta rajoittavan viljelykasvin kasvua, mikä on perusteltu oletus hyvin hoidetulla lohkolla.

Valittu kasvimalli voidaan luokitella deterministisiin malleihin, mikä on aiemmin todettu tärkeäksi mallin ominaisuudeksi (Park ym. 2005). Mallin vahvuus on sen yksinkertainen rakenne ja sen myötä saavutettu alhainen mallissa käytettyjen parametrien lukumäärä (Taulukko 1). Auringon säteilyn rajoittaman kasvun kuvaamiseen tarvitaan arvot kuudelle parametrille: taimen massa $\left(\mathrm{m}_{\mathrm{s}}\right)$, taimitiheys (SD), biomassan jakautuminen lehtiin ja juuriin (LWR), lehden pinta-ala jaettuna lehden massalla (SLA), säteilyn käytön tehokkuus (RUE) ja säteilyn suurin intensiteetti, minkä lehti voi hyödyntää $\left(\mathrm{I}_{\mathrm{sat}}\right)$. 
Taulukko 1. Simuloinnissa käytetyt kasvimallin parametrien arvot (Hakojärvi et al. 2013b, c).

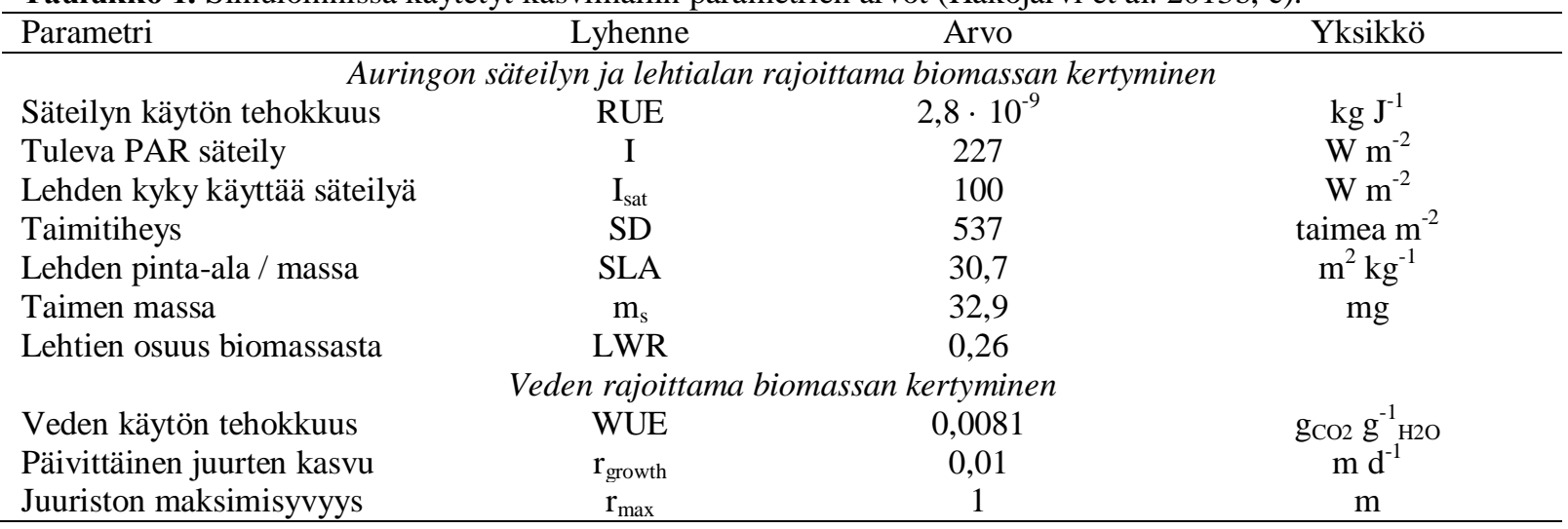

Kasvin biomassan (BM) kertyminen (kuiva-aineena sisältäen kaikki kasvin osat) eksponentiaalisen kasvun aikana lasketaan kaavalla 1:

$$
\left\{\begin{array}{l}
B M(t)=B M(0) \cdot e^{K \cdot t}=m_{s} \cdot S D \cdot e^{K \cdot t}, k u n L A I<\frac{I}{I_{\text {sat }}} \text { ja } t<t_{0} \\
t_{0}=\ln \left(\frac{I / I_{\text {sat }}}{B M(0) \cdot S L A \cdot L W R}\right) \cdot \frac{1}{K}, K=R U E \cdot I_{\text {sat }} \cdot L W R \cdot S L A
\end{array}\right.
$$

, jossa $\mathrm{t}$ on aika ja LAI kasvin lehtiala $\left(\mathrm{m}^{2}\right.$ lehteä $\mathrm{m}^{-2}$ maata). Kasvun alussa biomassan kertyminen on eksponentiaalista, koska lehtiala kasvaa ja sitä myötä myös kasvin fotosynteettisesti aktiivisen säteilyn (PAR) vastaanottokapasiteetti kasvaa. Eksponentiaalinen kasvu muuttuu lineaarikseksi ajanhetkellä $\mathrm{t}_{0}$, jolloin kasvi kykenee täysin hyödyntämään kaiken tulevan fotosynteettisesti aktiivisen säteilyn (I) lehtialallaan. Ajanhetkestä $\mathrm{t}_{0}$ eteenpäin biomassan kertyminen lasketaan kaavalla 2:

$$
B M(t)=B M\left(t_{0}\right)+R U E \cdot I \cdot\left(t-t_{0}\right), \text { kun } L A I>\frac{I}{I_{\text {sat }}} j a t>t_{0} .
$$

Jotta pystyttäisiin laskemaan veden rajoittaman biomassan kertyminen, täytyy malliin sisällyttää kaavat kasvin veden saannin ja kulutuksen laskentaan (Kaava 3). Veden kulutukseen laskentaan käytetään parametria, joka kuvaa kasvin tehokkuuden käyttää vettä (WUE). Käytännössä se tarkoittaa veden liikkumista kasvin lehtien ilmaraoista ympäröivään ilmaan hiilidioksidin $\left(\mathrm{CO}_{2}\right)$ hankkimisen yhteydessä. Veden saatavuus kasville riippuu juuriston syvyydestä sekä maan ominaisuuksista juuriston vyöhykkeellä. Juurten pitenemistä ja juuriston syvenemistä kuvaava parametri ( $\mathrm{r}_{\text {growth }}$ ) pidettiin vakiona koko kasvukauden ajan. Maan veden varastointikykyä puolestaan kuvaavat parametrit kenttäkapasiteetti (FC) ja lakastumisraja (PWP). Yksinkertaisimmillaan veden rajoittaman biomassan kertyminen voidaan laskea kaavan 3 mukaan:

$$
B M(t)=\left((F C-P W P) \cdot r_{\text {depth }}(t)+R(t)-E(t)\right) \cdot \rho_{\text {vesi }} \cdot W U E \cdot \frac{M_{g l c}}{M_{\mathrm{CO}_{2}}} .
$$

Kaavassa 3 maan kosteuden oletetaan pysyvän kenttäkapasiteetissa kunnes juuret siihen ylettävät. Maan veden varastointikyvyn ja kasvin juuriston lisäksi kasville käyttökelpoisen veden määrää lisää sadanta (R) ja vähentää evaporaatio maan pinnasta (E). Tilavuusperusteisesti laskettu kasville käyttökelpoisen veden määrä muutetaan massaperusteiseksi veden tiheyden $\left(\rho_{\text {vesi }}\right)$, vedenkäytön tehokkuuden ja moolimassojen (glukoosi $\mathrm{M}_{\mathrm{glc}}$ ja hiilidioksidi $\mathrm{M}_{\mathrm{CO} 2}$ ) suhteen avulla (Hautala ja Hakojärvi 2011). Kaavassa 3 oletetaan myös, että veden kapillaarinen nousu on maassa merkityksetöntä ja että juuristo ei ulotu ojitussyvyyden alapuolelle (jolloin maan kosteus > FC). Tässä tutkimuksessa maan kosteuden laskentaan käytettiin erillistä mallia, joka kuvataan seuraavassa kappaleessa. 


\section{Maan kosteuden mallintaminen}

Tässä tutkimuksessa maan kosteutta mallinnettiin yksinkertaisella astiamallilla (Hakojärvi ym. 2008), jossa maa on jaettu $0,1 \mathrm{~m}: n$ kerroksiin tarkasteltavan profiilin syvyydeltä (tässä tutkimuksessa $0-1,0$

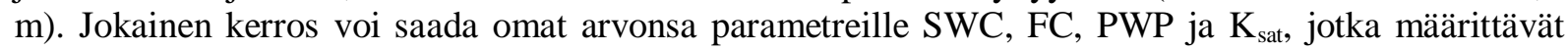
veden liikkumisen maassa. Mallissa vesi liikkuu kerroksesta alempaan vain, jos maan kosteus kyseisessä kerroksessa ylittää kenttäkapasiteetin, joka tutkitusti pitää hyvin paikkansa savisilla mailla (Aura 1990). Tämän jälkeen veden virtausta kerroksesta toiseen rajoittaa $K_{\text {sat. }}$ sekä alapuolella olevan kerroksen kosteus. Ensimmäisen kerroksen alapuolisten kerroksien kosteus ei saa nousta korkeammaksi kuin SWC. Ensimmäiseen kerrokseen voi määrällisesti suuren sateen jälkeen kertyä enemmän vettä kuin sinne mahtuu, jolloin SWC:n ylittävä kosteuslukema kertoon maan pinnalle kerääntyneestä vedestä.

Maan kosteuden mallissa evaporaatio kuivaa ensimmäistä kerrosta. Suurimmillaan evaporaatio on 5 mm vuorokaudessa, mutta se pienenee lineaarisesti ensimmäisen kerroksen kuivuessa ja lehtialan kasvaessa. Evaporaation lisäksi maasta poistuu vettä transpiraation ja ojituksen kautta. Kasvin haihduttaman veden määrä määräytyy kasvimallissa ja maasta se poistuu juuriston syvyyden sekä mallin kerrosten kosteuden mukaan. Ojituksen kautta poistuvan veden määrä lasketaan mallin alimmasta maakerroksesta, jolloin maaprofiilista poistuvan veden virtauksen määräävät alimman kerroksen kosteus ja $\mathrm{K}_{\text {sat }}$ sekä ojituksen kapasiteetti. Ojituksen kapasiteetiksi tässä tutkimuksessa valittiin $8,6 \mathrm{~mm}$ vuorokaudessa, joka on tasaisten alueiden salaojituksen ohjearvo tiiviille maalajeille (Saavalainen 1984).

\section{Sadantamalli}

Koska tässä tutkimuksessa haluttiin selvittää maan vedenpidätyskyvyn ja läpäisevyyden vaikutus biomassa kertymiseen pitkällä aikavälillä, kasvukausien välillä varioitiin vain sadantaa. Jokaiselle simuloidulle kasvukaudelle luotiin sadanta omalla mallillaan (Kilpeläinen ym. 2008). Malli perustuu 50 vuoden aikana Helsingissä kerättyyn säädataan ja sillä pystytään luomaan tilastollisesti samanlaista sadantaa kuin havaintojakson aikana on havaittu. Mallissa uuden sateen luominen perustuu kolmeen kumulatiiviseen jakaumaan: yksittäisen sateen kesto, määrä ja sateiden välinen aika. Näiden jakaumien avulla luotiin Monte Carlo menetelmällä sadanta halutulle ajanjaksolle. Satunnaisluvuilla luotiin vuorotellen arvot sateen kestolle, määrälle ja kuivan jakson kestolle. Tätä toistettiin niin kauan, että kasvukauden mittainen sadanta oli luotu. Simuloituina kasvukausina satoi keskimäärin $135 \mathrm{~mm}$ kasvukauden aikana, kun alhaisin sadesumma oli 54 mm ja korkein 294 mm (Kuva 1).
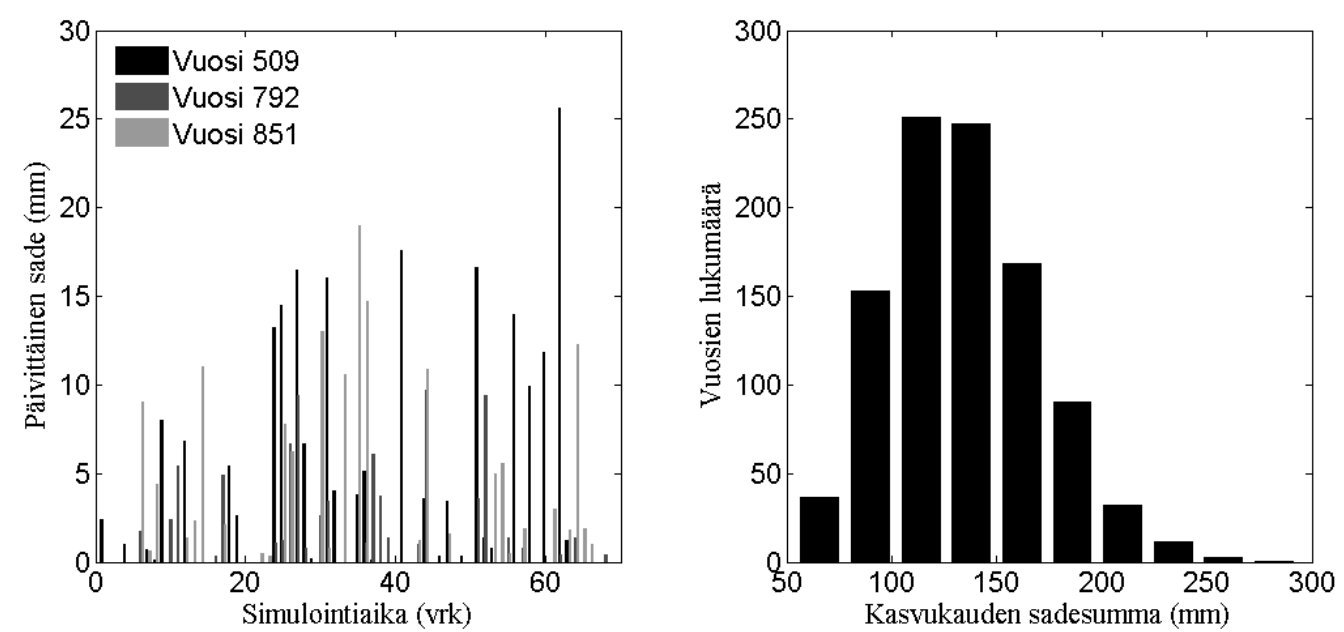

Kuva 1. Simuloitu päivittäinen sade kolmen satunnaisesti valitun vuoden aikana ja histogrammi kaikista simuloiduista sadannoista.

\section{Biomassasadon simulointi}


Edellä kuvattua kasvimallia ja maan veden mallia käytettiin maksimaalisen biomassan kertymisen paikkakohtaiseen simulointiin kaikilla kolmella tutkimukseen valitulla lohkolla. Kasvin kasvua simuloitiin tässä tutkimuksessa puolen tunnin aikavälillä. Auringon säteilystä oli käytettävissä vain vuorokausikohtaiset PAR arvot, joista laskettiin arvot puolen tunnin aikavälille sinifunktion avulla olettaen päivä vakio pituiseksi (15 tuntia). Sademallilla simuloitiin jokaiselle kasvukaudelle oma sadantansa, joka oli ainoa muuttuja kasvukausien välillä. Simuloitu viljelykasvi oli kevätvehnä, jonka biomassan kertymistä simuloitiin paikkakohtaisesti jokaisella lohkolla 1000 kasvukauden ajan. Tästä syystä kasvimallin parametrien arvot ja syöttötiedot olivat jokaisella simulointikerralla samat poislukien sadanta, joka oli erilainen jokaiselle simuloidulle kasvukaudelle.

Käytetty kasvimalli ei sisällä laskentaa kasvin fysiologiselle kehitykselle, mistä johtuen simulointiaika rajoitettiin vegetatiivisen kasvun ajalle taimettumisesta alkaen. Kasvukauden pituus simuloinneissa oli vakio, 69 vuorokautta. Simuloinnin alkuhetkellä maan kosteuden oletettiin koko profiilin syyvyydellä olevan kenttäkapasiteetissa. Tällöin jokaisen simuloidun sijainnin alkuhetken kosteus määräytyi paikkakohtaisten maan ominaisuuksien perusteella. Kaikki vuosien välinen vaihtelu sadossa yksinomaan sadannasta, koska se oli ainoa muuttuva tekijä simuloitujen kasvukausien välillä. Lohkon sisäinen vaihtelu johtuu puolestaan maan ominaisuuksien spatiaalisesta vaihtelusta.

Simuloidun biomassasadon vaihtelua lohkon sisällä ja vuosien välillä tutkittiin tunnusluvulla, joka kehitettiin lohkon sisäisen satovaihtelun kartoittamiseen satokartoista (Blackmore ym. 2003). Kaikkien lohkojen jokaisen sijainnin sadolle laskettiin ajallinen varianssi $\left(\sigma_{i}^{2}\right)$ :

$\sigma_{i}^{2}=\frac{1}{n} \sum_{t=1}^{n}\left(Y_{t, i}-\bar{Y}_{t}\right)$

jossa i on sijainti lohkolla, $\mathrm{t}$ on aika vuosina välillä $1 \ldots \mathrm{n}, \mathrm{Y}_{\mathrm{t}, \mathrm{i}}$ on simuloitu sato vuonna t sijainnissa $\mathrm{i}$ ja $\bar{Y}_{t}$ on keskimääräinen simuloitu sato koko lohkon alalta vuonna t. Ajallinen keskisato laskettiin jokaiselle pisteelle simuloitujen vuosien sadon keskiarvona.

\section{Simuloidut peltolohkot}

Tässä tutkimuksessa hyödynnettiin aiemmin päättyneissä MaSa 1 (2002-2004) ja MaSa 2 (20062008) projekteissa, joissa kerättiin paikkakohtaista informaatiota yhteensä kuudelta eri peltolohkolta. Tähän tutkimukseen valittiin yhteensä kolme lohkoa, joista kaksi (myöhemmin Lintupaju ja Kotkanoja) sijaitsi Jokioisilla $\left(60^{\circ} 49^{\prime} \mathrm{N}, 2^{\circ} 28^{\prime} \mathrm{E}\right)$ ja yksi (myöhemmin Vihti) Vihdissä $\left(60^{\circ} 21^{\prime} \mathrm{N}\right.$, $24^{\circ} 22^{\prime} \mathrm{E}$ ). Kaikilla valituilla lohkoilla maan savespitoisuus oli korkea (Lintupajun maalaji HtS-As, Kotkanojan As, Vihdin HHt-HsS) (Hakojärvi ym. 2013a, Ristolainen ym. 2006).

Maaperän ominaisuuksia mitattiin Lintupajulla 20 pisteestä, Kotkanojalla 19 pisteestä ja Vihdissä 24 pisteestä. Jokioisilla lohkoista tehtiin määritykset kolmelta toiminnalliselta syvyydeltä: kyntökerros $(0-0,2 \mathrm{~m})$, jankko $(0,2-0,35 \mathrm{~m})$ ja pohjamaa $(0,35-0,6 \mathrm{~m})$ (Ristolainen ym. 2006). Vihdissä maaperästä otettiin $200 \mathrm{~cm}^{3}$ häiriintymättömät näytteet kahdelta syvyydeltä: $0,05-0,1 \mathrm{~m}$ ja 0,3-0,35 m. Näiltä kolmelta lohkolta simuloinnissa käytettiin paikka- ja syvyyskohtaisia arvoja seuraavista maan ominaisuuksista: SWC, FC, PWP ja $\mathrm{K}_{\text {sat }}$ (Hakojärvi ym. 2013a, b).

\section{Tulokset ja tulosten tarkastelu}

Simuloitujen biomassasatojen perusteella lohkot tarjosivat hieman toisistaan poikkeavat kasvuolot viljelykasville. Lohkon sisäinen sadonvaihtelu oli pienintä Lintupajussa ja Vihdissä, joissa ajallinen keskihajonta oli huomattavasti pienempää kuin Kotkanojalla (Kuva 2). Vihti oli kuitenkin näistä lohkoista satoisin $12 \mathrm{t} \mathrm{ha}^{-1}$ keskisadolla (Kuva 2). Blackmoren ym. (2003) mukaan lohko voidaan jakaa neljään erilaiseen tuotantoalueeseen. Lohkon keskisato tarkastellun ajan yli jakaa pellon korkea satoiseen ja matala satoiseen alueeseen suhteuttaen paikkakohtaiset sadot lohkon keskisatoon (pystyviivat, Kuva 2). Vaakaviiva (Kuva 2) puolestaan jakaa sekä korkea että matala satoiset alueet epävakaasti ja vakaasti satoa tuottaviin osiin. Vaakaviivan sijoittamiseen Blackmore ym. (2003) eivät antaneet tarkempaa ohjeistusta ja siksi kuvassa 2 vaakaviiva sijoitettiin ajallisen keskihajonnan mediaanin kohdalle, joka laskettiin kullekin lohkolle erikseen. Viljelytoimenpiteiden kannalta helpoimpia alueita pellosta edustavat vaakaviivan alle jäävät alueet, jotka tuottavat ajallisen 
keskisatonsa mukaista satoa suhteellisen vakaasti. Täsmäviljelylle otollisia alueita taas ovat alueet, jotka jäävät vaakaviivan yläpuolelle, koska näissä sato vaihtelee vuosien välillä suhteellisen paljon.

Sijainteja, joissa ajallinen keskihajonta oli suurta, tarkasteltiin yksityiskohtaisemmin satotason mukaan. Simuloinnissa käytetyt maaperän ominaisuudet (SWC, FC, PWP ja $\mathrm{K}_{\text {sat }}$ ) eivät näissä sijainneissa poikenneet merkittävästi toisistaan, huolimatta eroista ajallisessa keskisadossa. Maan hyötykapasiteetti (FC-PWP) oli huomattavasti korkeampi Lintupajulla $\left(0,16 \pm 0,006 \mathrm{~m}^{3} \mathrm{~m}^{-3}\right)$ ja Vihdissä $\left(0,16 \pm 0,01 \mathrm{~m}^{3} \mathrm{~m}^{-3}\right)$ sijainneissa, joissa ajallinen keskisato oli korkea ja keskihajonta suurta kuin sijainneissa, joissa ajallinen keskisato oli matala ja keskihajonta suurta (Lintupaju 0,13 $\pm 0,006$ $\mathrm{m}^{3} \mathrm{~m}^{-3}$, Vihti $\left.0,14 \pm 0,005 \mathrm{~m}^{3} \mathrm{~m}^{-3}\right)$.
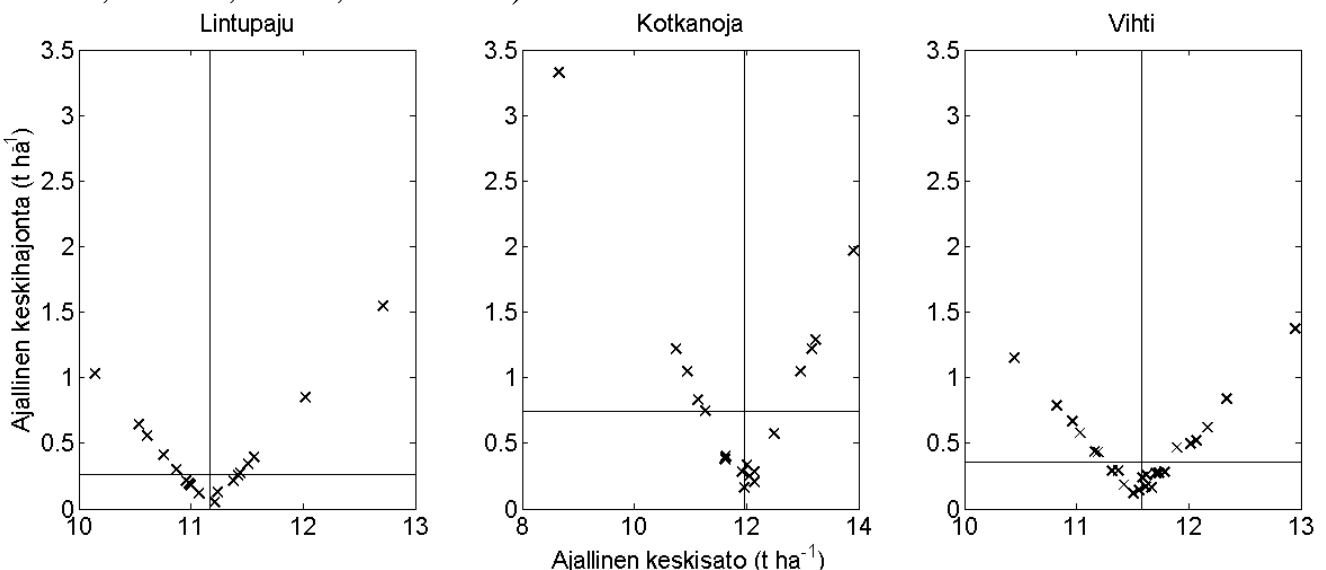

Kuva 2. Paikkakohtaisesti simuloidun biomassan kertymän ajallinen hajonta esitettynä sijaintikohtaisen keskisadon funktiona. Pystyviiva kuvassa osoittaa lohkon keskisadon simuloituna vuosina ja vaakaviiva ajallisen keskihajonnan mediaanin kyseiseltä lohkolta.

Sadannan määrän vaikutusta tarkasteltiin valitsemalla poikkeuksellisen vähä- tai runsassateiset (kasvukauden sadesumma $<80 \mathrm{~mm}$ tai $>180 \mathrm{~mm}$ ) kasvukaudet kaikista simuloiduista kasvukausista. Sadannan määrällä oli huomattavan suuri vaikutus kaikkien lohkojen satoon, koska kasvukauden sateen määrän kasvu nosti satoa kaikissa simuloiduissa sijainneissa (Kuva 3). Simuloinneissa liiallinen vesi ei rajoita kasvua, mikä ei välttämättä täysin vastaa todellisuutta kaikissa tapauksissa, mutta toisaalta liian märät olosuhteet ovat ojituksella torjuttavissa maalajin asettamiin rajoihin asti.
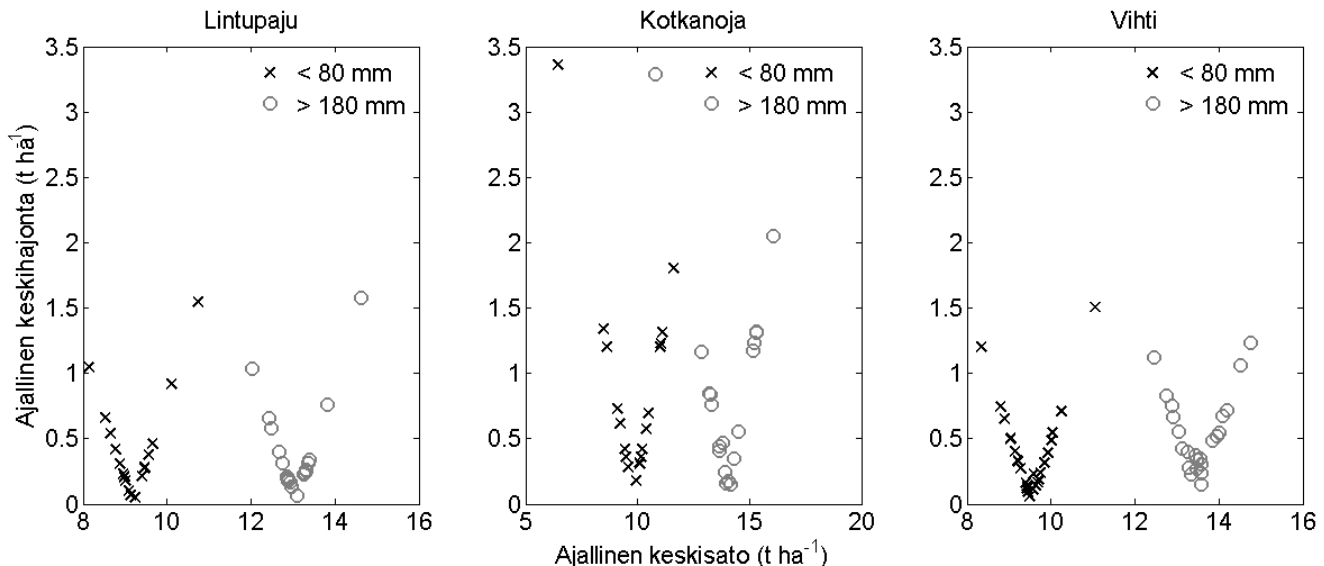

Kuva 3. Simuloitu biomassasato vuosina, jolloin sadanta on ollut poikkeuksellisen korkea tai alhainen.

Poikkeuksellisen vähäsateisia vuosia simuloituna 1000 vuoden jaksona oli 45 ja poikkeuksellisen sateisia 114.

Simulointituloksien biomassan kertymän ajallinen vaihtelu johtui yksinomaan muutoksista sateessa, koska kaikki muut tekijät pidettiin kasvukausien välillä vakioina. Samoin lohkojen sisäinen vaihtelu johtui vain ja ainoastaan vaihtelusta maan ominaisuuksissa. Aiemmissa tutkimuksissa on epäilty maan ominaisuuksilla olevan merkittävä vaikutus sadon vaihteluun lohkon sisällä ja lohkojen välillä (Cox ym. 2003, Derby ym. 2005, James ja Godwin 2003, Keller ym. 2012, Timlin ym. 2001). Esitettyjen simuloititulosten perusteella simuloinnissa käytetyt maan ominaisuudet ( $\mathrm{SWC}, \mathrm{FC}, \mathrm{PWP}$ ja $\mathrm{K}_{\text {sat }}$ ) vaikuttivat lohkojen paikkakohtaiseen biomassan kertymään ja vaihteluun. Näistä tekijöistä johtuva 
vaihtelu oli kuitenkin suhteellisen pientä verrattuna lohkoilta mitattuun sadon vaihteluun (Hakojärvi ym. 2013b). Tästä johtuen näiden kolmen lohkon kohdalla pelkästään tieto maan mitattujen ominaisuuksien vaihtelussa ei riitä täsmäviljelytoimenpiteisiin, kuten lannoituksen kohdentamiseen lohkojen sisällä. Simulointitulokset pystyvät kuitenkin osoittamaan ne sijainnit, joissa sato saattaa vähäsateisena kesänä jäädä alhaiseksi maan veden varastointikapasiteetista johtuen.

Yleisesti ottaen Blackmoren ym. (2003) esittelemällä menetelmällä voidaan tehokkaasti erottaa ne alueet lohkolla, missä sato poikkeaa lohkon keskisadosta. Sijainnit, joissa sadon ajallinen hajonta on suurta, ovat potentiaalisia kohteita täsmäviljelytoimepiteille tai niissä voi olla tarvetta perusparannuksille. Toisaalta sellaiset lohkon alueet, joissa sato on toistuvasti samalla tasolla, mutta poikkeaa lohkon keskisadosta, jäävät tällä menetelmällä löytymättä. Tämä olisi mahdollista pienellä muutoksella kaavaan 4 (Hakojärvi ym. 2013b). Menetelmä perustuu satokarttojen tarjoaman tiedon käyttämiseen. Sadonmittauslaitteisto on vielä melko harvinainen varuste Suomen oloissa käytettävässä puimurissa. Menetelmälle saattaa kuitenkin tulevaisuudessa olla käyttöä satomittarien yleistyessä puimurikannan uudistumisen myötä.

\section{Johtopäätökset}

Sadannan vaihtelun vaikutusta satoon ja sadon vaihteluun selvitettiin simuloimalla sateen ja PAR:n rajoittamaa biomassan kertymistä. Simulointi suoritettiin kolmelle eri lohkolle, joista oli aiemmin paikkakohtaisesti mitattu maan ominaisuuksia (SWC, FC, PWP ja $\mathrm{K}_{\text {sat }}$ ). Simulointi suoritettiin 1000 kasvukauden ajan ja paikkakohtaisilla maan ominaisuuksilla havaittiin olevan vaikutusta lohkon sisäiseen sadon vaihteluun. Simuloinnissa käytettyjen maan ominaisuuksien aiheuttama sadonvaihtelu oli melko pientä, myös verrattuna lohkoilta kolmena peräkkäisenä vuotena mitattuun sadonvaihteluun. Näiden kolmen lohkon kohdalla maan ominaisuuksien vaikutus sadon vaihteluun ei ollut kovin suuri verrattuna muihin sadon vaihtelua aiheuttaviin tekijöihin, huolimatta edeltävissä tutkimuksissa esitetyistä olettamuksista.

Lohkon sisäisen ja vuosien välisen biomassan kertymän vaihtelun arviointiin käytetty menetelmä todettiin tehokkaaksi havaitsemaan lohkon alueet, joilla sato poikkeaa lohkon keskisadosta. Lohkon alueet, joissa satotaso on vakaa, mutta poikkeaa lohkon keskisadosta, saattavat kuitenkin jäädä tunnistamatta tätä menetelmää käyttäen. Menetelmä on tehokas työkalu, kun halutaan selvittää onko lohkolla alueita, joilla voisi olla tarvetta täsmäviljelytoimenpiteille tai mahdollisesti perusparannuksille. Menetelmän käyttöä Suomessa saattaa kuitenkin rajoittaa se, että tällä hetkellä vain harvalla tilalla on käytettävissä useamman vuoden ajalta paikkakohtaista satotietoa eli satokarttoja.

\section{Kiitokset}

Tämän tutkimuksen rahoitti Maatalouskoneiden tutkimussäätiö. Maa- ja vesitekniikan tuki ry ja Maaja metsätalousministeriö rahoittivat MaSa1 ja 2 projekteja, joissa kerättyä paikkakohtaista informaatiota käytettiin tässä tutkimuksessa. Kiitämme Marja-Liisa Westerlundia, Matti Ylösmäkeä ja Ilkka Sarikkaa ammattitaitoisesta työstä sekä kentällä, että laboratoriossa.

\section{Kirjallisuus}

Aura, E. 1990. Salaojien toimivuus savimaassa. Maatalouden tutkimuskeskus. Tiedote 10/90. Jokioinen: Maatalouden tutkimuskeskus. ISSN 0359-7652.

Basso, B., Ritchie, J.T., Cammarano, D. \& Sartori, L. 2011. A strategic and tactical management approach to select optimal $\mathrm{N}$ fertilizer rates for wheat in a spatially variable field. European Journal of Agronomy, 35:215222.

Blackmore, S., Godwin, R.J. \& Fountas, S. 2003. The analysis of spatial and temporal trends in yield map data over six years. Biosystems Engineering, 84, 455-466.

Cox, M.S., Gerard, P.D., Wardlaw, M.C. \& Abshire, M.J. 2003. Variability of selected soil properties and their relationship with soybean yield. Soil Science Society of America Journal 67: 1296-1302.

Derby, N.E., Steele, D.D., Terpstra, J., Knighton, R.E. \& Casey., F. X. M. 2005. Interaction of nitrogen, wheather, soil, and irrigation on corn yield. Agronomy Journal, 97: 1342-1351. 
Godwin, R.J., Wood, G.A., Taylor, J.C., Knight, S.M. \& Welsh, J.P. 2003. Precision Farming of Cereal Crops: a Review of a Six Year Experiment to develop Management Guidelines, Biosystems Engineering, 84(4): 375-391.

Hakojärvi, M., Hautala, M. \& Ahokas, J. 2008. Simulation of fully-automatic crop farming in Finland. International Conference on Agricultural Engineering 2008, Hersonissos - Crete, Greece.

Hakojärvi, M., Hautala, M., Ristolainen, A. \& Alakukku. L. 2013a. Clay soil water retention properties and spatio-temporal yield variation of spring cereals. European Journal of Agronomy, 49: 1-11.

Hakojärvi, M., Hautala, M., Ristolainen, A. \& Alakukku. L. 2013b. Spatial and temporal yield variation in three different clay soil fields. Teoksessa: Agricontrol. 2013. s. 196-201.

Hakojärvi, M., Hautala, M. \& Alakukku. L. 2013c. Testing the use of an analytical C3 - biomass accumulation model for precision fertilization. Käsikirjoitus.

Hautala, M. \& Hakojärvi, M. 2011. An analytical C3-crop growth model for precision farming. Precision Agriculture 12: 266-279.

James, I.T. \& Godwin, R.J. 2003. Soil, water and yield relationships in developing strategies for the precision application of nitrogen fertiliser to winter barley. Biosystems Engineering 84: 467-480.

Keller, T., Sutter, J.A., Nissen, K. \& Rydberg, T. 2012. Using field measurement of saturated soil hydraulic conductivity to detect low-yielding zones in three Swedish fields. Soil \& Tillage Research 124: 68-77.

Kilpeläinen, T., Tuomenvirta, H. \& Jylhä, K. 2008. Climatological characteristic of summer precipitation in Helsinki during the period 1951-2000, Boreal Environment Research 13: 67-80.

Park, S.J., Hwang, C.S. \& Vlek, P.L.G. 2005. Comparison of adaptive techniques to predict crop yield response under varying soil and land management conditions. Agricultural Systems 85: 59-81.

Risius, H. \& Korte, H. 2010. Process analysis for grain flow segregation. Landtechnik 65: 34-37.

Ristolainen, A., Nuutinen, V. \& Alakukku, L. 2006. Comparison of some soil physical properties of two clay fields. Proceedings of ISTRO 17th Triennial Conference 'Sustainability - its Impact on Soil Management and Environment', Kiel, Germany.

Saavalainen, J. 1984. Salaojittajan käsikirja. Osa II A: Salaojituksen suunnittelu. Salaojakoulutuksen kannatusyhdistys.

Shanahan, J. F., Kitchen, N. R., Raun, W. R. \& Schepers, J. S. 2008. Responsive in-season nitrogen management for cereals. Computers and electronics in agriculture 61: 51-62.

Timlin, D., Pachepsky, Y., Walthall, C. \& Loechel, S. 2001. The use of a water budget model and yield maps to characterize water availability in a landscape. Soil \& Tillage Research 58: 219-231.

Welsh, J. P., Wood, G. A., Godwin, R. J., Taylor, J. C., Earl, R., Blackmore, S. \& Knight, S. M. 2003 a. Developing Strategies for Spatially Variable Nitrogen Applications in Cereals, Part I: Winter Barley. Biosystems Engineering 84: 481-494.

Welsh, J. P., Wood, G. A., Godwin, R. J., Taylor, J. C., Earl, R., Blackmore, S. \& Knight, S. M. 2003 b. Developing Strategies for Spatially Variable Nitrogen Applications in Cereals, Part II: Wheat. Biosystems Engineering 84: 495-511.

Wood, G.A., Welsh, J.P., Godwin, R.J., Taylor, J.C., Earl, R. \& Knight, S.M. 2003. Real-time Measures of Canopy Size as a Basis for Spatially Varying Nitrogen Applications to Winter Wheat sown at Different Seed Rates. Biosystems Engineering 84: 513-531. 